\title{
Adaptation of rice to climate change through a cultivar-based simulation: a possible cultivar shift in eastern Japan
}

\author{
Ryuhei Yoshida $^{1,6, *}$, Shin Fukui ${ }^{2,3}$, Teruhisa Shimada ${ }^{4}$, Toshihiro Hasegawa ${ }^{2}$, \\ Yasushi Ishigooka ${ }^{2}$, Izuru Takayabu ${ }^{5}$, Toshiki Iwasaki ${ }^{1}$ \\ ${ }^{1}$ Graduate School of Science, Tohoku University, Sendai 980-8578, Japan \\ ${ }^{2}$ Agro-Meteorology Division, National Institute for Agro-Environmental Sciences, Tsukuba 305-8604, Japan \\ ${ }^{3}$ Faculty of Human Sciences, Waseda Univeristy, Tokorozawa 359-1192, Japan \\ ${ }^{4}$ Graduate School of Science and Technology, Hirosaki University, Hirosaki 036-8561, Japan \\ ${ }^{5}$ Meteorological Research Institute, Tsukuba 305-0052, Japan \\ ${ }^{6}$ Present address: Faculty of Symbiotic Systems Science, Fukushima University, Fukushima 960-1296, Japan
}

\begin{abstract}
As surface warming threatens rice production in temperate climates, the importance of cool regions is increasing. Cultivar choice is an important adaptation option for coping with climate change but is generally evaluated with a single metric for a few hypothetical cultivars. Here, we evaluate adaptation to climate change based on multiple metrics and cultivars in presently cool climates in Japan. We applied the outputs of a global climate model (MIROC5) with a Representative Concentration Pathways 4.5 scenario, dynamically downscaled to a $10 \mathrm{~km}$ mesh for the present (1981-2000) and future (2081-2099) climate conditions. The data were input into a ricegrowth model, and the performances of 10 major cultivars were compared in each mesh. With the present-day leading cultivars, the model predicted reduced low-temperature stress, a regional average yield increase of $17 \%$, and several occurrences of high-temperature stress. The most suitable cultivars in each grid cell changed dramatically because of climate change when a single metric was used as a criterion, and the yield advantage increased to $26 \%$. When yield, cold, and heat stress were taken into account, however, the currently leading cultivars maintained superiority in $64 \%$ of the grid cells, with an average regional yield gain of $22 \%$, suggesting a requirement for developing new cultivars by pyramiding useful traits. A trait such as low sensitivity to temperature for phenology helps in ensuring stable growth under variable temperatures. Increasing photoperiod sensitivity can be an option under future climates in relatively warmer regions.
\end{abstract}

KEY WORDS: Rice cultivar $\cdot$ Yield $\cdot$ High-temperature stress $\cdot$ Low-temperature stress $\cdot$ Climate change

Resale or republication not permitted without written consent of the publisher

\section{INTRODUCTION}

Recent and projected surface warming has the potential to negatively affect crop growth (Porter et al. 2014); therefore, climate change related impact assessments are required for ensuing food security. Climate change scenarios from global climate models are widely used as input in crop-growth models, and global impact assessments have been conducted for major crops, such as wheat, maize, and rice (Parry et al. 2004, Lobell \& Field 2007, Deryng et al. 2011, 2014, Rosenzweig et al. 2014). Regional impact assessments for major crop species have also been reported in various regions (reviewed by Porter et al. 2014) considering their respective agro-ecosystems and projected climatic changes. In Asia, rice is the most important food crop and impact assessments for rice have been carried out in various regions (e.g. 
Tao et al. 2008, Iizumi et al. 2011, Kim et al. 2013, Soora et al. 2013, Yu et al. 2014).

Rice production is sensitive to considerable variation in various climatic factors, including atmospheric $\mathrm{CO}_{2}$ concentrations, precipitation, solar radiation, and temperatures, all of which are projected to change in the future. Among these factors, high- and low-temperature extremes in the reproductive growth phases are serious concerns (Wassmann et al. 2009) because they cause floret sterility, which reduces grain yield (Satake 1976, Satake \& Yoshida 1978). In temperate rice-growing countries such as Japan, cool-summer damages have been a major yield constraint for many years (Satake 1976), but heatinduced sterility is also emerging as a result of recent hot-summer events (Hasegawa et al. 2011) and will become a serious threat to rice production in Japan (Nakagawa et al. 2003).

The effects arising from predicted changes in climate will differ, even within Japan. According to Iizumi et al. (2011), the probability of a decrease in rice yield in the 2090s relative to the 1990 s is $>20 \%$ for western Japan, whereas it is $<10 \%$ in eastern Japan, where current temperatures are lower. Rice quality is currently deteriorating in western Japan because of high temperatures, and this is projected to continue under future climate conditions (Okada et al. 2011). While high-temperature stress is not presently evident in eastern Japan, climate change would bring this stress to presently cool regions as well (Nemoto et al. 2012). In eastern Japan, cold damage caused by a local northeasterly wind known as Yamase is a more serious threat to crop growth than heat damage (Shimono 2011). The frequency of Yamase airflows is projected to decrease in the future, but the event will still occur (Kanno et al. 2013) and cool-summer damages to rice are projected to persist under future climate conditions (Kanda et al. 2014). However, because surface warming caused by climate change has the potential to negatively affect rice growth in currently warm regions, such as in low-latitude or western Japan (e.g. Iizumi et al. 2007), rice production in presently cool regions (e.g. eastern Japan) is becoming more significant for a stable food supply (Nakagawa et al. 2003, Easterling et al. 2007, Shimono 2011).

Climatic conditions at each site affect farmers' choice of cultivars, which is one of the most important options for agricultural management. The choice of cultivars will become even more important in the future because they are considered to be the most effective adaptation measures against climate change (Porter et al. 2014). For this reason, a number of simulations were conducted to examine the impact of climate change on currently planted cultivars and cultivars adapted to projected climate change conditions based on a single metric, namely grain yield (reviewed by Porter et al. 2014). These simulations most commonly use one or a few hypothetical cultivars that match growth duration in new climates based on the altered thermal time requirements, assuming a linear response of developmental rate to temperature (e.g. Challinor et al. 2009, Yu et al. 2014, Kassie et al. 2015). Because most crop models predict shorter growth duration due to warmer climate, which leads to less biomass accumulation, and thus reduction in yield, varieties with longer thermal time requirements (i.e. late maturation) than the current varieties are expected to be more productive in warmer climates. However, rice is a short-day crop, and phenological traits of cultivars are determined by a combination of different degrees of photoperiod and temperature sensitivities. Replacement of the currently planted cultivars with those planted in warmer climates is tempting, but whether this simple solution is an alternative should be examined based on the realistic representation of the phenological traits of the cultivars. Previously, we evaluated phenological traits of various major cultivars, which cover more than $80 \%$ of the current rice harvest area in Japan (Fukui et al. 2015). By incorporating these parameters into a rice growth model, we can evaluate the adaptability of major rice cultivars to new environments.

In this study, we aimed to determine the suitability of the response of rice cultivars to climate change in the presently cool regions in Japan. To objectively determine the spatial distribution of the most suitable cultivar, we simulated grain yields of 10 major rice cultivars for $10 \mathrm{~km}$ gridded cells under current and projected future climatic conditions. Because both low and high temperatures are concerns in the current and future climates, we introduce these metrics as criteria for cultivar rankings in addition to grain yield. A consideration of multiple metrics together, such as yield and stress, for a multiple-cultivar choice would offer useful information on the efficacy of cultivar replacement and traits of cultivars conferring adaptability to climate change.

\section{METHODS}

\subsection{Downscaling of the climate change scenario}

We used the outputs of the global climate model (GCM) Model for Interdisciplinary Research on Cli- 
mate (MIROC5; Watanabe et al. 2010) using the Representative Concentration Pathways (RCP) 4.5, because the climate data for Asia have focused on the Yamase airflow (Kanno et al. 2013). The original $150 \mathrm{~km}$ grid mesh resolution is insufficient for resolving regional differences in the meteorological elements of eastern Japan; therefore, we used the $20 \mathrm{~km}$ mesh MIROC5 output dataset for Japan based on the method of Ishizaki et al. (2012; Fig. 1). We downscaled the data to a $10 \mathrm{~km}$ mesh for eastern Japan in the JMA-NHM regional climate model $\left(\mathrm{RCM}_{\text {; }}\right.$ Saito et al. 2007). The JMA-NHM model utilizes the KainFritsch scheme for convective parameterization (Kain 2004) and the improved Mellor-Yamada Level 3 scheme for turbulent parameterization (Nakanishi \& Niino 2004). The downscaling was conducted for the key growing period, from May 28 to August 31, for 1981-2000 (present climate) and 2081-2099 (future climate), and the first $4 \mathrm{~d}$ were used as a spin-up period and excluded from the analysis.

Outputs from GCMs and RCMs are generally biased by the observed values (e.g. Yoshida et al. 2012a). To avoid biases, we used changes in the climatological mean (20 yr mean for present climate and $19 \mathrm{yr}$ mean for future climate), rather than the original, downscaled climate data. Based on previous studies (Kimura \& Kitoh 2007, Iizumi et al. 2010, Yoshida et al. 2012b), the following procedures were conducted to compose the climate datasets. First, the gridded, observed dataset from the Automated Meteorological Data Acquisition System (Mesh-AMeDAS; Seino 1993) for 1981-2000 was defined as the present climate. Then, the future climate was calculated from climate differences derived from the downscaled data and the Mesh-AMeDAS data. Here, differences (i.e. difference $=$ future - present) were calculated for the daily maximum, mean, and minimum temperatures, and the multiplying ratios (ratio $=$ future/present) were calculated for downward shortwave radiation, relative humidity, and wind speed. This method was used to account for the impacts of summer climate change on rice production.

\subsection{Rice yield simulation}

To account for cultivar-based rice production, we modified the Hasegawa/Horie rice-growth model (H/H model; Hasegawa \& Horie 1997, Nakagawa et al. 2005, Fukui et al. 2015) to incorporate responses to extreme temperatures and $\mathrm{CO}_{2}$ based on climate change studies, which are outlined below.

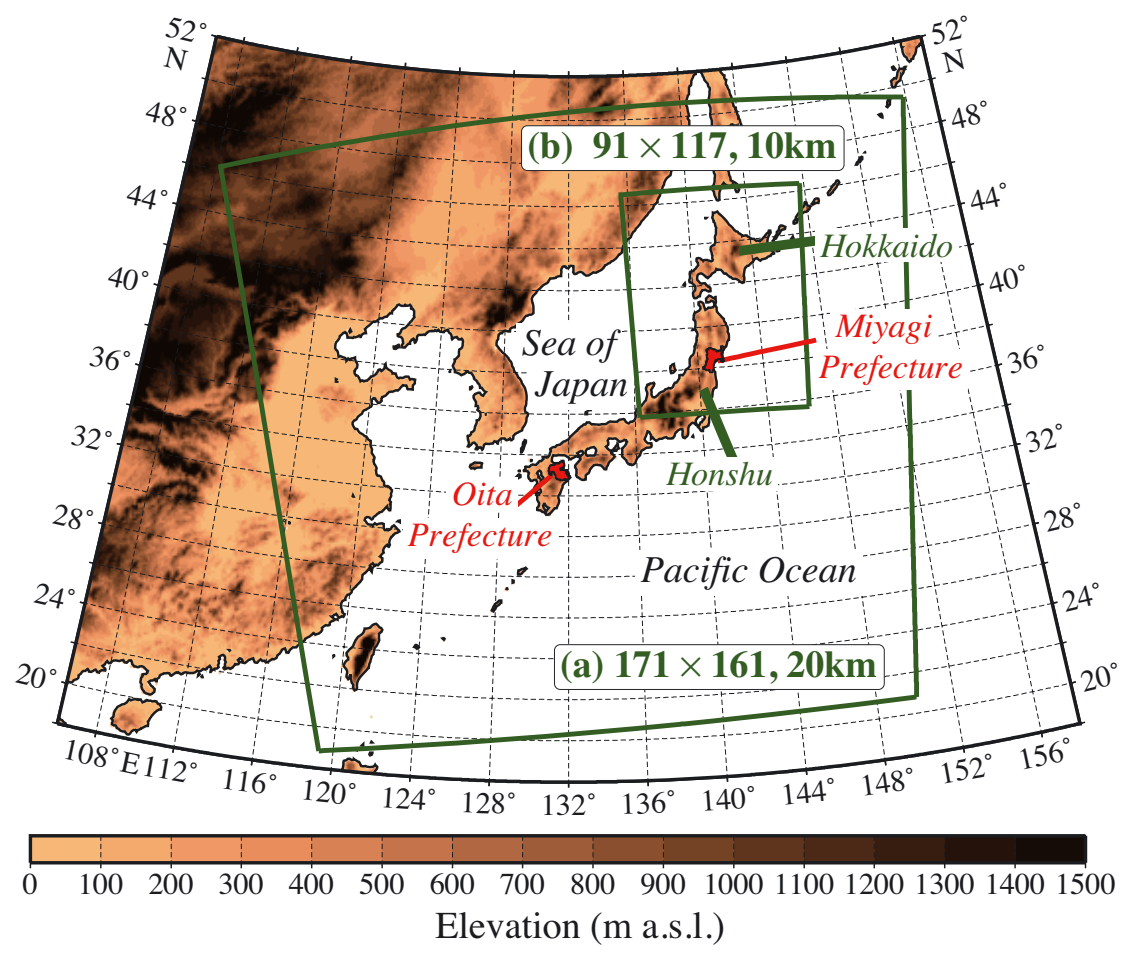

Fig. 1. Calculation domain used for the Japan Meteorological Agency nonhydrostatic model (JMA-NHM) simulations. (a) Outer domain: $171 \times 161$ grids with $20 \mathrm{~km}$ spacing for the dataset based on the method in Ishizaki et al. (2012). (b) Inner domain: $91 \times 117$ grids with $10 \mathrm{~km}$ spacing for the JMA-NHM model simulation

\subsubsection{Stomatal conductance}

Rising atmospheric $\mathrm{CO}_{2}$ concentrations will enhance photosynthesis and reduce stomatal conductance. In this model, we used a combination of the Farquhar-von Caemmerer-Berry (FvCB) photosynthesis model (Farquhar et al. 1980) and the Ball-Berry (BB) stomatal conductance model (Collatz et al. 1991) to account for the $\mathrm{CO}_{2}$ response. Two key parameters in the FvCB model, the maximum rate of

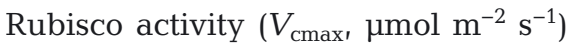
and potential rate of electron transport $\left(J_{\max }, \mu \mathrm{mol} \mathrm{m}{ }^{-2} \mathrm{~s}^{-1}\right)$, were expressed as linear functions of specific leaf nitrogen $\left(\mathrm{SLN}, \mathrm{g} \mathrm{m}^{-2}\right.$ ) derived from leaflevel gas exchange measurements in controlled chamber experiments (data presented in Hasegawa et al. 2015):

$V_{\mathrm{cmax}}=\max [86 \times(\mathrm{SLN}-0.5), 0]$

$J_{\max }=\min \{\max [138 \times(\mathrm{SLN}-0.4)$,

$0], 210\}$ 
The other parameters for the FvCB model were from Medlyn et al. (1999). Stomatal conductance $\left(g_{\mathrm{c}}, \mathrm{mol} \mathrm{m}^{-2} \mathrm{~s}^{-1}\right)$ was then given by the BB model:

$$
g_{c}=\frac{b_{1} \times A_{f} \times \mathrm{RH}}{C_{a}}+b_{0}
$$

where $A_{\mathrm{f}}$ is the assimilation rate obtained from the FvCB model, $\mathrm{RH}$ is the relative humidity (dimensionless), $C_{\mathrm{a}}$ is the atmospheric $\mathrm{CO}_{2}$ concentration, and $b_{0}$ and $b_{1}$ are empirical parameters (0.00001 and 5.9; Katul et al. 2000).

\subsubsection{Phenology}

Rice phenology is simulated by a development index (DVI; 0 = seeding emergence, 1 = panicle initiation, 2 = heading, and 3 = maturity). The DVI value increases daily, and its development rate (DVR) is controlled by the air temperature and photoperiod (Nakagawa et al. 2005) as follows:

$$
\operatorname{DVR}= \begin{cases}\frac{f_{1}(T) g(L)}{G_{1}}, & (0 \leq \mathrm{DVI}<2) \\ f_{2}(T), & (2 \leq \mathrm{DVI} \leq 3)\end{cases}
$$

where $T$ indicates the average temperature between the daily maximum and minimum temperatures, $L$ denotes the photoperiod, $G_{1}$ is the parameter. Each respective development function was expressed as follows:

$$
f_{1}(T)= \begin{cases}\left\{\left(\frac{T-T_{\min }}{T_{o}-T_{\min }}\right)\left(\frac{T_{\max }-T}{T_{\max }-T_{o}}\right)^{\frac{T_{\max }-T_{o}}{T_{o}-T_{\min }}}\right\}^{\alpha}, \quad\left(T_{\min }<T<T_{\max }\right) \\ 0, \quad\left(T<T_{\min } \text { or } T_{\max }<T\right)\end{cases}
$$$$
g(L)= \begin{cases}\left\{\left(\frac{L}{L_{\min }}\right)\left(\frac{L_{\max }-L}{L_{\max }-L_{\min }}\right)^{\frac{L_{\max }-L_{\min }}{L_{\min }}}\right\}^{\beta}, & \left(L_{\min }<L<L_{\max }\right) \\ 1, & \left(L<L_{\min }\right)\end{cases}
$$

$$
f_{2}(T)= \begin{cases}\frac{1}{G_{2}}\left[1.0-\mathrm{e}^{-A\left(T-T_{C}\right)}\right], & \left(T_{C}<T\right) \\ 0, & \left(T \leq T_{C}\right)\end{cases}
$$

where $T_{\max }$ and $T_{\min }$ are the maximum and minimum temperatures in terms of the growth thresholds (fixed at 42 and $8^{\circ} \mathrm{C}$ ) (Yin et al. 1997). $L_{\max }$ and $L_{\min }$ are maximum and minimum photoperiods (24 and $10 \mathrm{~h}$ ), and $\alpha, \beta, A, G_{2}, T_{\mathrm{o}}$ and $T_{\mathrm{c}}$ are cultivar-dependent parameters. We analyzed 10 Japanese cultivars developed in the cool-temperate and temperate climates (Table 1).

\subsubsection{Yield and temperature stress}

Rice growth is sensitive to the daily maximum and minimum temperatures after initiation of the panicle (Horie et al. 1999):

$$
Y=\frac{H_{V}}{0.85}\left\{M_{a} \times[1-f(\mathrm{HDD})] \times[1-f(\mathrm{CDD})]\right\}
$$

where $Y$ is the yield (unhulled grain weight expressed at the $15 \%$ moisture content, $\mathrm{g} \mathrm{m}^{-2}$ ), $H_{\mathrm{v}}$ is the potential harvest index $(0.5), M_{\mathrm{a}}$ is the mass above the ground $\left(\mathrm{g} \mathrm{m}^{-2}\right)$, and $f(\mathrm{HDD})$ and $f(\mathrm{CDD})$ are the high- and low-temperature stress functions (i.e. fertility under the high-temperature stress and sterility under the low-temperature stress; value range: $0=$ free to 1 = stress). Each stress function was calculated according to Horie et al. (1999):

$$
\begin{gathered}
f(\mathrm{HDD})=\left(1+\mathrm{e}^{k 1 \times \mathrm{HDD}}\right)^{-1} \\
\mathrm{HDD}=36.6-\frac{1}{n} \sum_{\mathrm{DVI}=1.6}^{2.2} T_{x} \\
f(\mathrm{CDD})=\frac{\max \left[100-\left(\gamma_{0}+k_{2} \times \mathrm{CDD}^{y}\right), 0\right]}{100 \times\left[1+\mathrm{e}^{-6.2 \times(\mathrm{DVI}-2.29)}\right]} \\
\mathrm{CDD}=\sum_{\mathrm{DVI}=1.5}^{2.2} \max (22-T, 0)
\end{gathered}
$$

where HDD is the heating degree-days $\left({ }^{\circ} \mathrm{C}\right), n$ is the number of days during the flowering period (d), $T_{X}$ is the daily maximum temperature $\left({ }^{\circ} \mathrm{C}\right), \mathrm{CDD}$ is the cooling degree-days $\left({ }^{\circ} \mathrm{C}\right)$, and $k_{1}, \gamma_{0}, k_{2}$, and $y$ are the empirical parameters $(8.53,4.6,0.054$, and 1.56, respectively). Although this scheme excludes cultivar differences, the simulated stress values differed for each cultivar, because the growth rate was cultivardependent, as shown in the parameters in Table 1 and Eqs. (4-7). We defined the yield attained in the absence of stress as the potential yield.

\subsubsection{Yield and temperature stress simulation}

Using the climate data and the H/H model, we conducted the following analyses:

(1) climate change scenarios for eastern Japan were analyzed for the meteorological elements that were used in the $\mathrm{H} / \mathrm{H}$ model.

(2) The reproducibility of the H/H model was evaluated by simulating rice yields using the MeshAMeDAS data for the present climate (1981-2000). In this simulation, we used the current leading cultivar of each prefecture (Japanese administrative dis- 
Table 1. Cultivars and parameters used in the H/H phenology scheme (Fukui et al. 2015). $G_{1}=$ minimum number of days required from emergence to heading under optimum conditions; $G_{2}=$ insensitiveness to temperature after heading; $\alpha$ and $\beta=$ sensitiveness to temperature and photoperiod before heading; $A=$ multiplying factor of temperature impact on growth after heading; $T_{\mathrm{o}}=$ optimum temperature before heading; $T_{\mathrm{C}}=$ minimum temperature required for growth. These parameters were estimated based on the days to heading observed in the nationwide variety trials (Fukui et al. 2015). Because dates for panicle initiation were not recorded in the database, development index (DVI) was assigned as 1 at heading and 2 at maturity. To conform to the Hasegawa/Horie $(\mathrm{H} / \mathrm{H})$ ricegrowth model, which assumes DVI = 1 at panicle initiation, 2 at heading and 3 at maturity, the estimated DVI values using the above parameters were corrected to the $0-3$ system scale assuming that panicle initiation occurs at DVI $=0.64$ in the $0-2$ system

\begin{tabular}{|c|c|c|c|c|c|c|c|c|}
\hline ID & Cultivar & $\begin{array}{l}G_{1} \\
\text { (d) }\end{array}$ & $\begin{array}{l}G_{2} \\
\text { (d) }\end{array}$ & $\alpha$ & $\beta$ & $\begin{array}{c}A \\
\left(\times 10^{-2}\right)\end{array}$ & $\begin{array}{c}T_{\mathrm{o}} \\
\left({ }^{\circ} \mathrm{C}\right)\end{array}$ & $\begin{array}{c}T_{\mathrm{c}} \\
\left({ }^{\circ} \mathrm{C}\right)\end{array}$ \\
\hline 1 & Hitomebore & 56.7 & 23.3 & 0.93 & 0.95 & 3.5 & 32.9 & 0.4 \\
\hline 2 & Kirara397 & 45.3 & 22.0 & 1.25 & 0.07 & 3.3 & 32.1 & 1.9 \\
\hline 3 & Hinohikari & 30.9 & 38.0 & 1.25 & 7.34 & 15.9 & 30.6 & 9.9 \\
\hline 4 & Asahinoyume & 30.9 & 35.8 & 1.07 & 6.70 & 9.9 & 31.3 & 4.3 \\
\hline 5 & Akitakomachi & 54.6 & 24.7 & 1.24 & 0.13 & 5.8 & 34.3 & 7.4 \\
\hline 6 & Aichinokaori & 30.7 & 29.9 & 1.48 & 7.90 & 6.2 & 28.3 & 4.9 \\
\hline 7 & Haenuki & 55.1 & 24.0 & 1.68 & 1.12 & 3.7 & 30.0 & 1.5 \\
\hline 8 & Koshiibuki & 59.0 & 23.6 & 1.20 & 0.45 & 6.1 & 32.3 & 10.0 \\
\hline 9 & Koshihikari & 36.6 & 29.1 & 1.11 & 3.42 & 5.3 & 34.6 & 0.2 \\
\hline 10 & Kinuhikari & 30.2 & 26.5 & 1.50 & 4.32 & 6.7 & 33.3 & 9.2 \\
\hline
\end{tabular}

the study regions. The H/H model simulates rice growth under no water limitation, and the paddy was assumed to be maintained in flooded condition, which is supported by the fact that $>99 \%$ of the rice-growing areas are fully irrigated. We compared the simulated yields with those obtained from the crop data on a sub-prefectural scale, as summarized by MAFF. Because the crop statistics by MAFF provided the hulled grain yield, we converted the yield to unhulled data multiplying it by 1.25 as reported by Yoshida (1981).

(3) Climate change impacts on rice yields and temperature stresses for the current cultivars were estimated using the projected future climate data. Planting times and $\mathrm{N}$ fertilizer amount were kept constant at the year 2000 values. The timing of the split-application of $\mathrm{N}$ fertilizer was determined according to the predicted phenology.

(4) Potential yield and temperature stresses under climate change conditions in all the grid cells were also examined for all 10 cultivars listed in Table 1 . On

trict) obtained from Crop Statistics of the Ministry of Agriculture, Forestry, and Fisheries (MAFF, data as of 2009, www.maff.go.jp/j/tokei/kouhyou/kensaku/ bunya2.html) for simulating yields in the grid cells for the 1981-2000 period. For all grid cells, the current leading cultivar corresponds to 1 of the 10 cultivars listed in Table 1. The amount of nitrogen fertilizer each year was given as follows. We obtained consumption of nitrogenous fertilizers for rice production from the Rice and Wheat Production Cost Statistics (MAFF 1981-2000, www.e-stat.go.jp/SG1/estat/List. do?bid=000001014632\&cycode $=0$ ) and calculated the elemental weight of $\mathrm{N}$ applied, which was then divided by the rice-planted area. Because this statistic provides only aggregated data for the regions covering several prefectures, $\mathrm{N}$ supply in the simulation was almost homogenous over the entire study area, as was the soil fertility. The time of transplanting by prefecture was fixed for each grid cell based on the Crop Statistics (MAFF, data as of 2000) for each prefecture. Nitrogen fertilizer was spilt-applied thrice during the growing season; $58 \%$ of the total $\mathrm{N}$ was applied immediately before planting and the remaining $42 \%$ in 2 equal splits during the panicle development $(21 \%$ each at about the spikelet differentiation stage and reduction division stage of the pollen mother cell), as commonly practiced by farmers in the basis of simulated yields, we selected a 'top cultivar' for each grid cell that provided the maximum yield among the 10 cultivars. We also counted the total number of top grid cells by cultivars, which was divided by the total number of analyzed grid cells (i.e. 1307). This ratio was defined as the share of each cultivar. For all crop simulations, grid cells with paddy-field ratios of $<1 \%$ in the National Land Numerical Information database (MLITT 2012) were defined as non-paddy areas and excluded from the analysis. The geographical distribution of paddy fields in 2006 (the latest available year) was applied and fixed throughout the analysis period.

\section{RESULTS}

\subsection{Effects of climate change on meteorological elements}

We estimated the present and future meteorological elements required for the $\mathrm{H} / \mathrm{H}$ model (Fig. 2). Temperature variables (daily mean, maximum, and minimum temperatures) showed similar geographical distributions, and surface warming was more evident in the northern area on the Pacific Ocean side (Fig. 2a-i). A regional average of $\sim 3^{\circ} \mathrm{C}$ of surface 


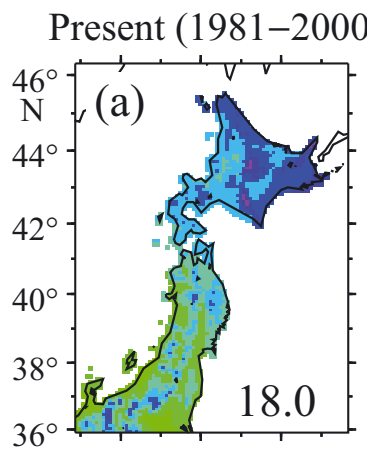

Future (2081-2099)

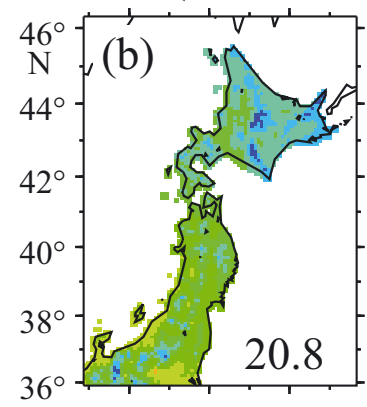

Temperature
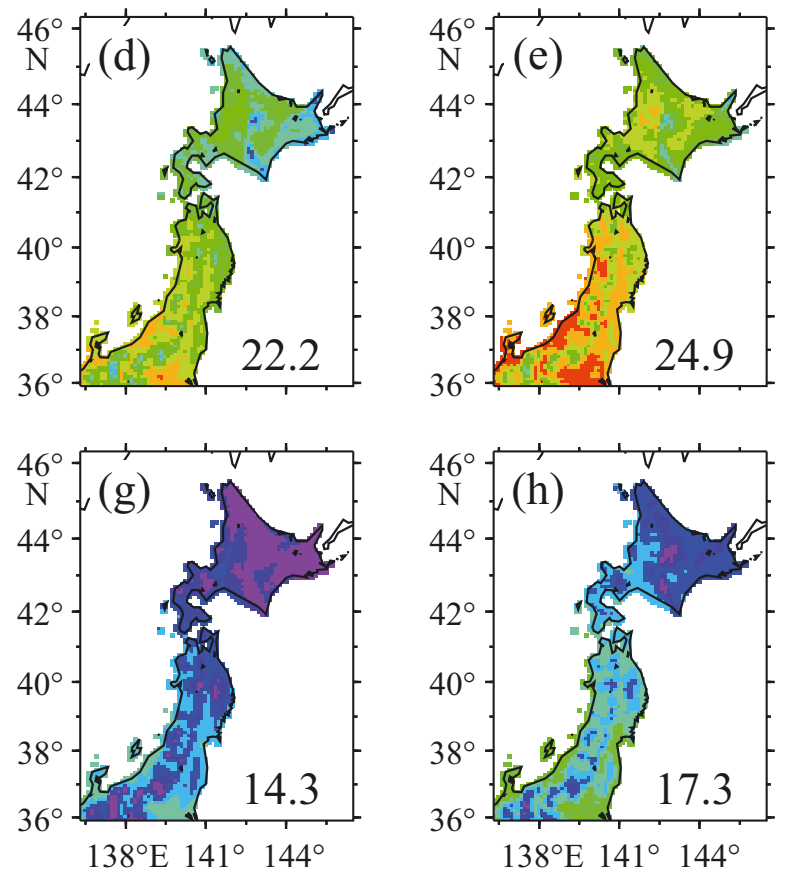

$\left({ }^{\circ} \mathrm{C}\right)$
$=28$
-24
-20
-20
-16
-12
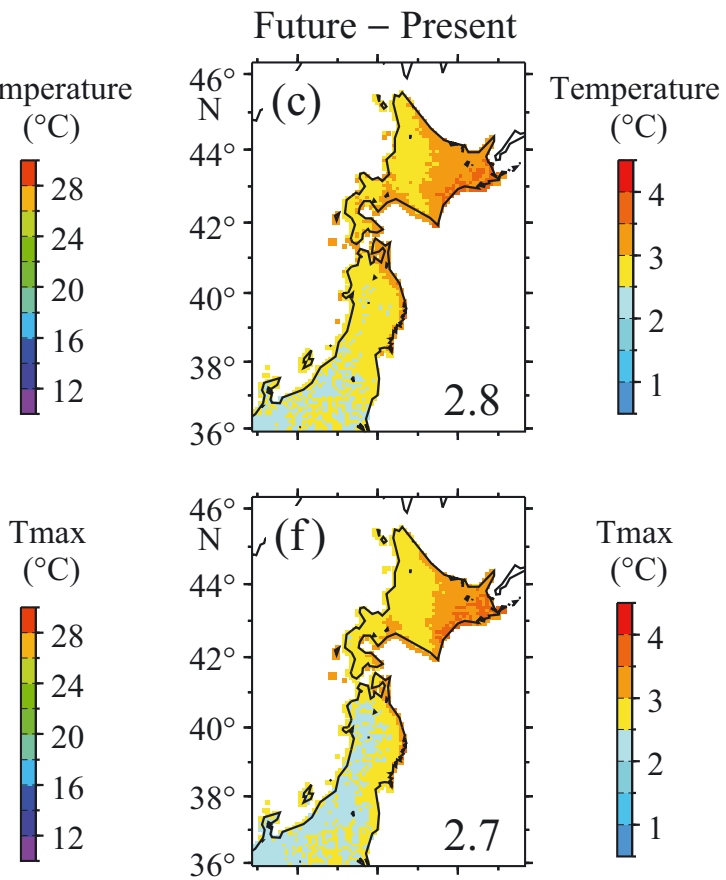

Tmin
$\left({ }^{\circ} \mathrm{C}\right)$
-28
-24
-24
-20
-16
-12

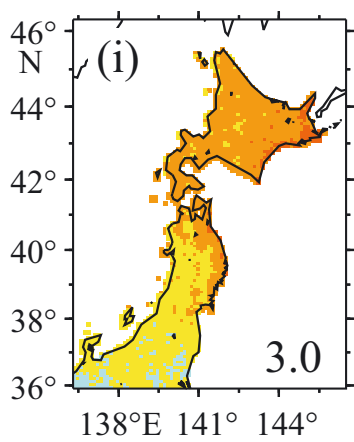

Tmin

$\left({ }^{\circ} \mathrm{C}\right)$

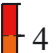

3

$-2$

$-1$

Fig. 2. (cont. on next page). Geographical distributions of the downscaled summer meteorological factors in the present and future climates, and their differences. Daily $(\mathrm{a}-\mathrm{c})$ mean, $(\mathrm{d}-\mathrm{f})$ maximum and $(\mathrm{g}-\mathrm{i})$ minimum temperatures

warming was obtained across the land surface, which fell within the 5 to $95 \%$ ranges for the global land-surface warming projected by the global climate models in the Coordinated Modeling Intercomparison Project Phase $5\left(1.3\right.$ to $\left.3.4^{\circ} \mathrm{C}\right)$ (Collins et al. 2013). Similar east-west geographical patterns were indicated for downward shortwave radiation in both present and future climates (Fig. $2 \mathrm{j}, \mathrm{k}$ ). A small increase $(<1 \%$ of the regional average) occurs over most of the area, and a relatively large increase $(\sim 10 \%)$ occurs in eastern Hokkaido (the northern island in the $10 \mathrm{~km}$ mesh domain, see Fig. 1) and the southern part of the analyzed area (Fig. 21). Relative humidity also showed similar geographical patterns but decreased slightly with climate change (Fig. 2m,n). The decrease appeared in most grid cells $(80.0 \%$ of the total land grid cells), but a small increase $(<1 \%)$ was also estimated for a part of the northern area (Fig. 2o). Future changes in wind speed were estimated to be the smallest among the elements analyzed. Although intensified wind speed was found in the western part of Hokkaido, its contribution was negligible compared with changes at the regional scale (Fig. 2p-r). These meteorological elements were utilized in the $\mathrm{H} / \mathrm{H}$ model to simulate the yield and temperature stresses.

\subsection{Reproducibility of the rice growth model}

We first examined the performances of the $\mathrm{H} / \mathrm{H}$ model by comparing the simulated yields with historical yield records between 1981 and 2000. Fig. 3 depicts the inter-annual variation of the observed 


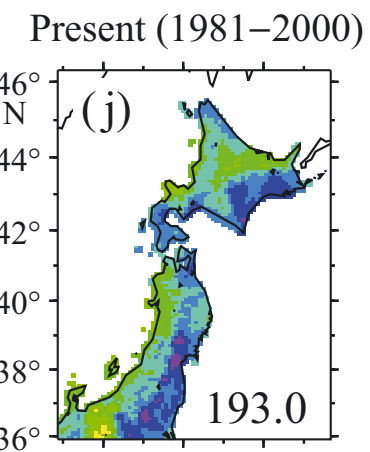

Future (2081-2099)
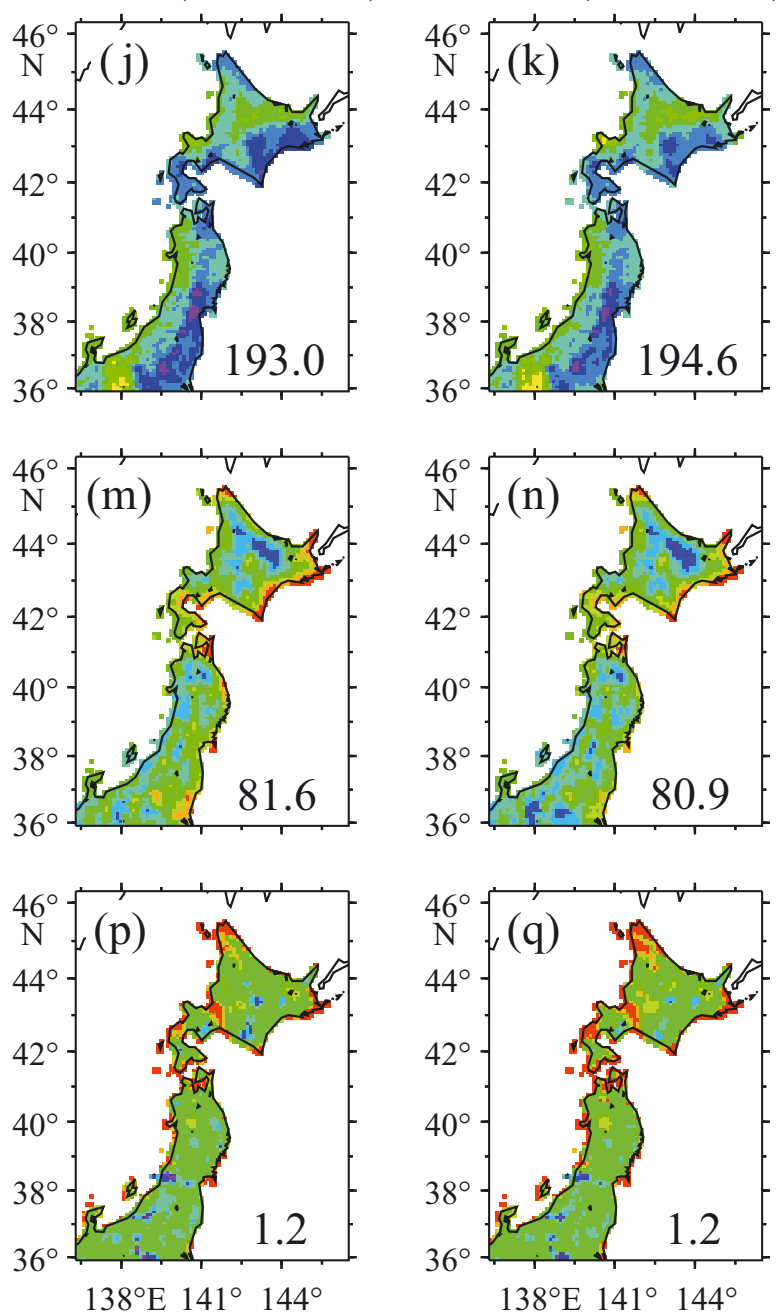

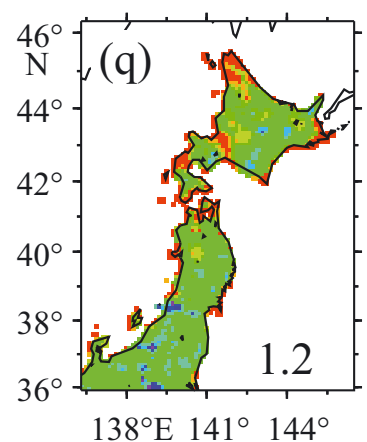

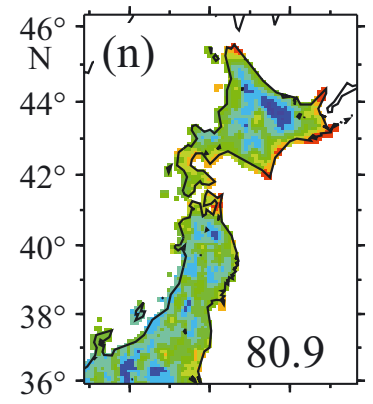

Future - Present

Radiation

( $\mathrm{W} \mathrm{m}^{-2}$ )
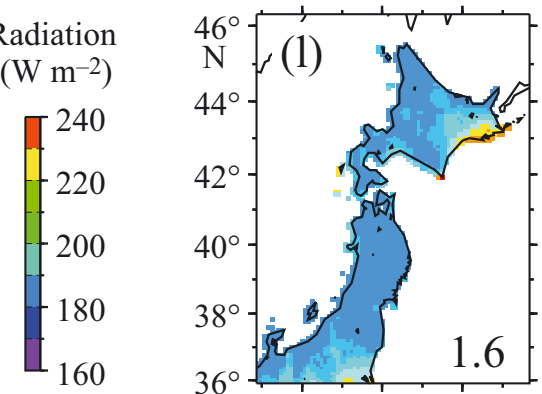

Radiation

( $\mathrm{W} \mathrm{m}^{-2}$ )

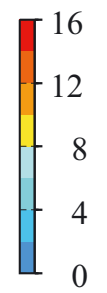

Rel. humidity
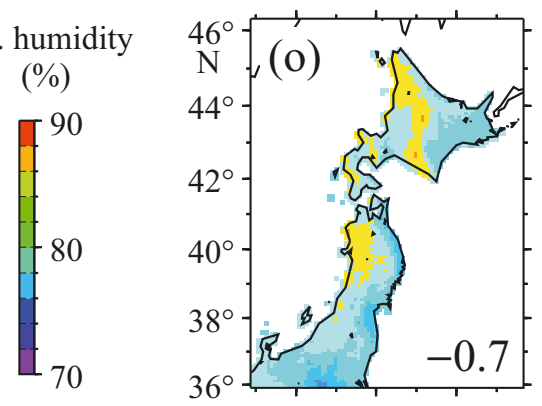

Rel. humidity

(\%)

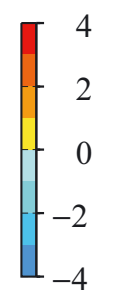

Wind speed $\left(\mathrm{m} \mathrm{s}^{-1}\right)$

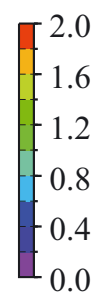

Wind speed

$\left(\mathrm{m} \mathrm{s}^{-1}\right)$

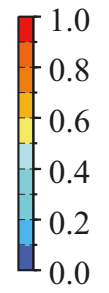

Fig. 2. (cont.). (j-l) Downward shortwave radiation at the surface; $(\mathrm{m}-\mathrm{o})$ relative humidity; and (p-r) wind speed. Bottom right value in each figure: regional average

and simulated yields for the period as an average over the grid cells with paddy fields $\geq 1 \%$. The $\mathrm{H} / \mathrm{H}$ model reasonably reproduced the inter-annual variation in the observed yield (Fig. 3a). The correlation coefficient (r) was 0.80 and the average bias $-1.8 \%$. The yield dropped sharply in 1993 because of a strong Yamase airflow, which resulted in severe cold damage to rice. The model simulated the large 1993 reduction in yield, reflecting a high $f(C D D)$ value (Fig. 3b). The simulation also predicted relatively low yields in other years, such as 1981, 1983, 1995, 1996, and 1997, when $f(C D D)$ exceeded 0.3, although the predicted yield reduction tended to be larger than the observed yield reduction.

The geographical distribution (Fig. 4) of the observed yield showed a small regional difference (mean \pm SD: $628.5 \pm 67.9 \mathrm{~g} \mathrm{~m}^{-2}$ ) because of the coarse

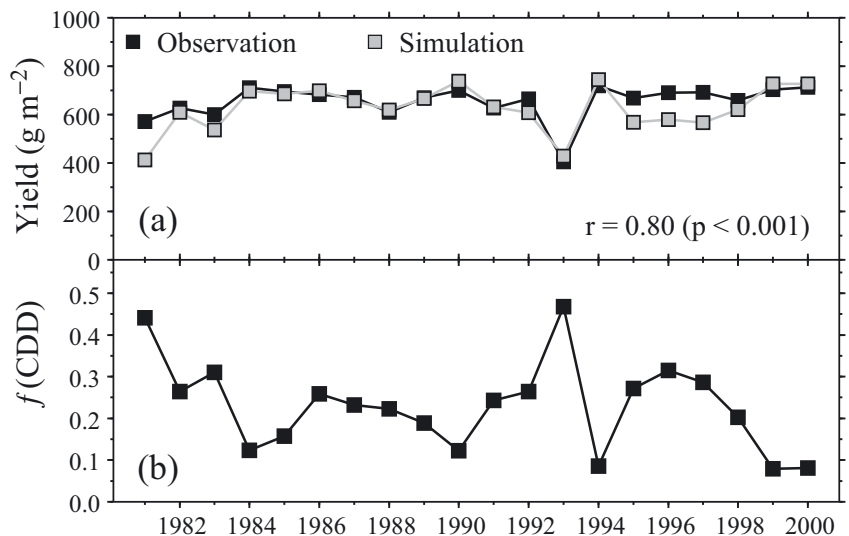

Fig. 3. (a) Interannual variation of observed and simulated yields from 1981 to 2000 averaged over the analyzed area. r: Pearson's correlation coefficient. (b) Same as (a) but for $f(C D D)$, the simulated low-temperature stress value 

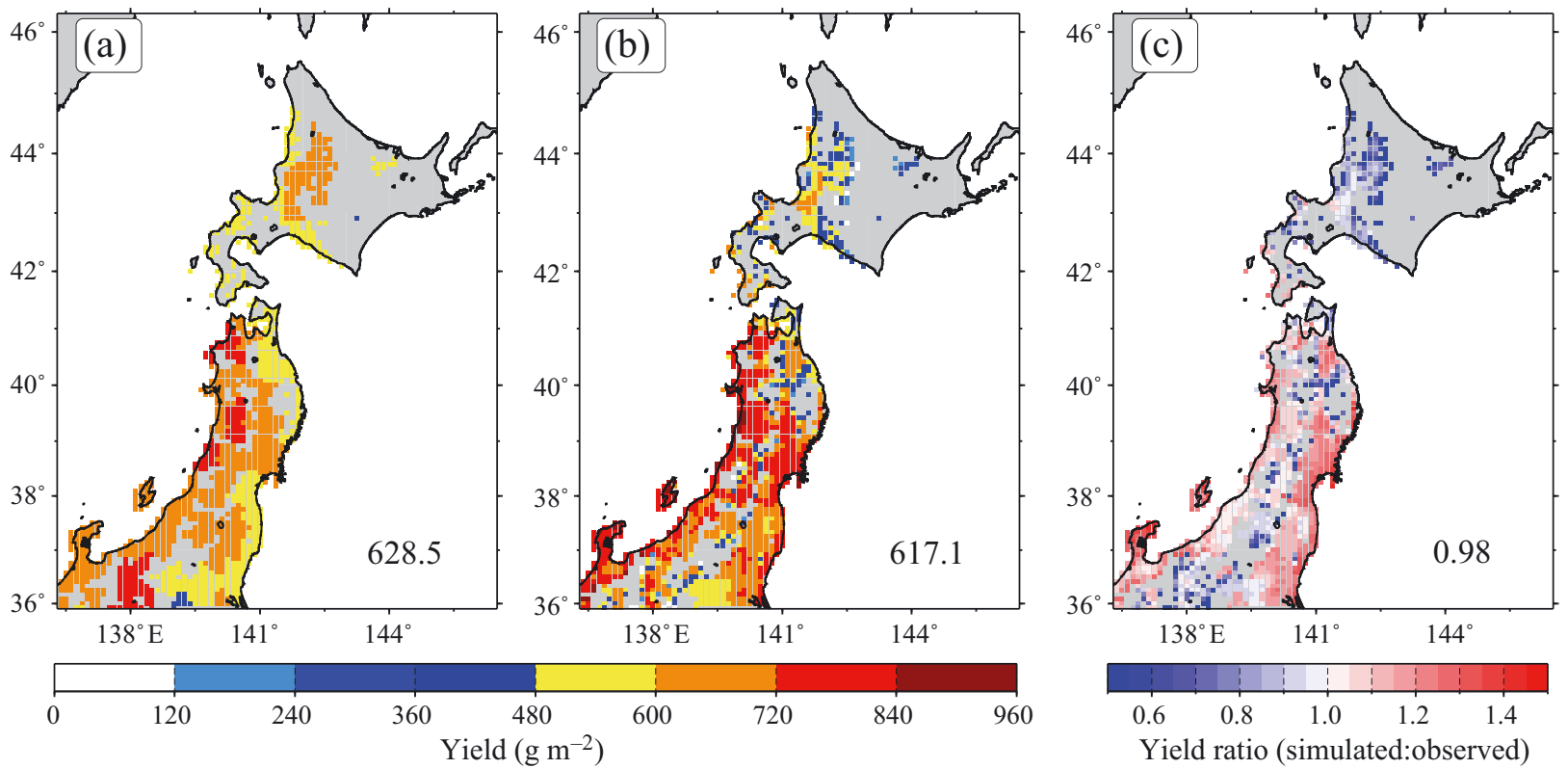

Fig. 4. Geographical distribution of the 20 yr (1981-2000) averaged yield. (a) Observation, (b) simulation, and (c) simulated: observed yield ratio. Gray: areas with $<1 \%$ paddy fields in the $10 \mathrm{~km}$ grid cells. Bottom right values: regional average

spatial resolution. The Crop Statistics reports yield data by several regional divisions in each prefecture. Although the horizontal resolutions differ because of the non-uniformity of the areas of the prefectures, all of the regional divisions are larger than the $10 \mathrm{~km}$ mesh used for downscaling. Because of the detailed meteorological elements derived from the downscaling, the simulated yield had larger geographical variations $\left(617.1 \pm 187.8 \mathrm{~g} \mathrm{~m}^{-2}\right)$ than the observations.

\subsection{Impact of climate change on rice yield}

By fixing the cropped cultivar as the current leading one, we estimated the climate change impacts on rice yield and temperature stresses. For the present climate, high yield (720 to $840 \mathrm{~g} \mathrm{~m}^{-2}$ ) in the analyzed area was found in the plains on the Japan Sea side (Fig. 5a). In most of Honshu (see Fig.1), this high yield was simulated for the future climate (Fig. 5b). The in-
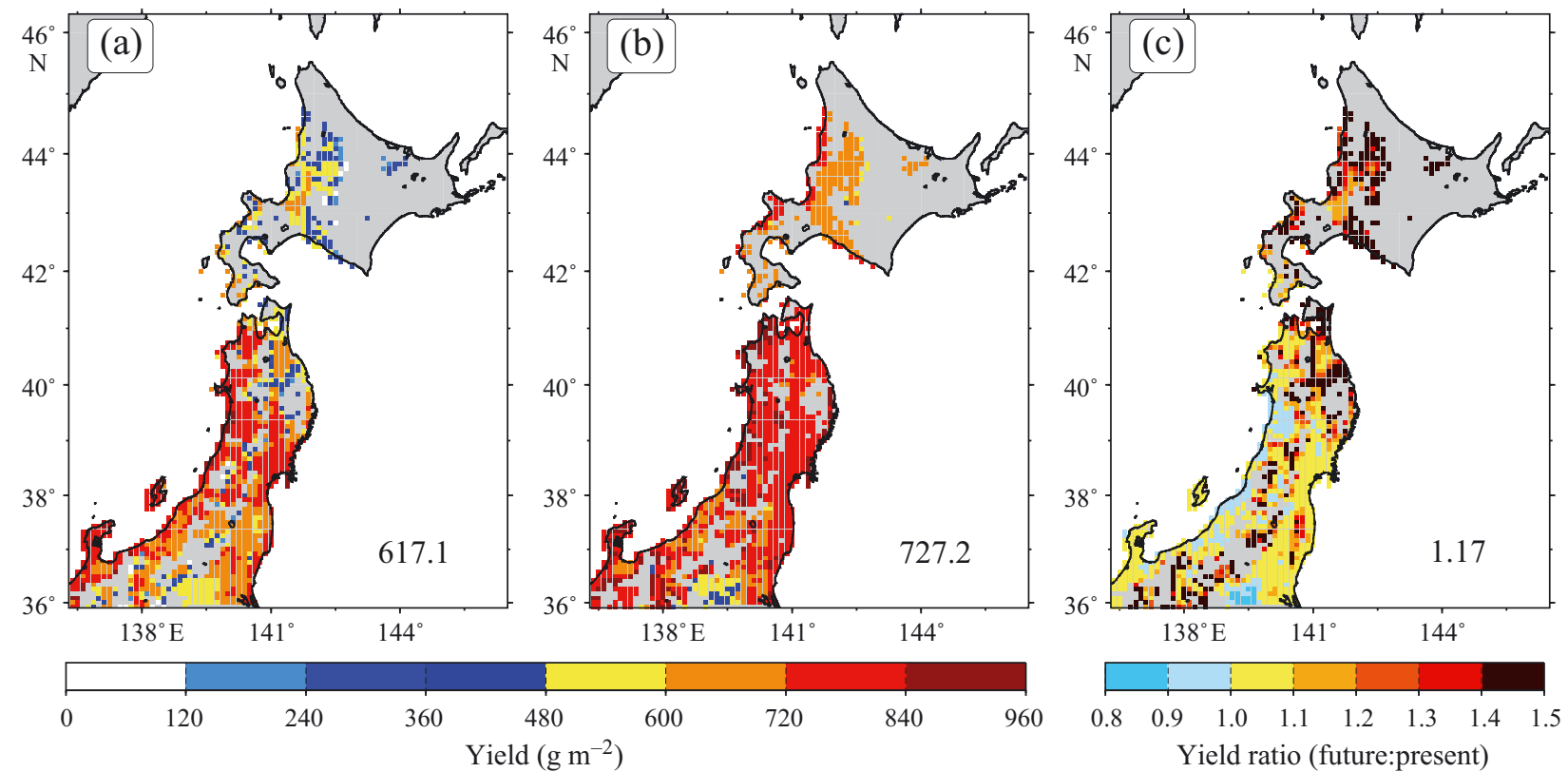

Fig. 5. Simulated yield for (a) present (1981-2000) and (b) future (2081-2099) climates, and (c) future:present yield ratio with the current leading cultivar. Bottom right values: regional average. Gray shading as in Fig. 4 

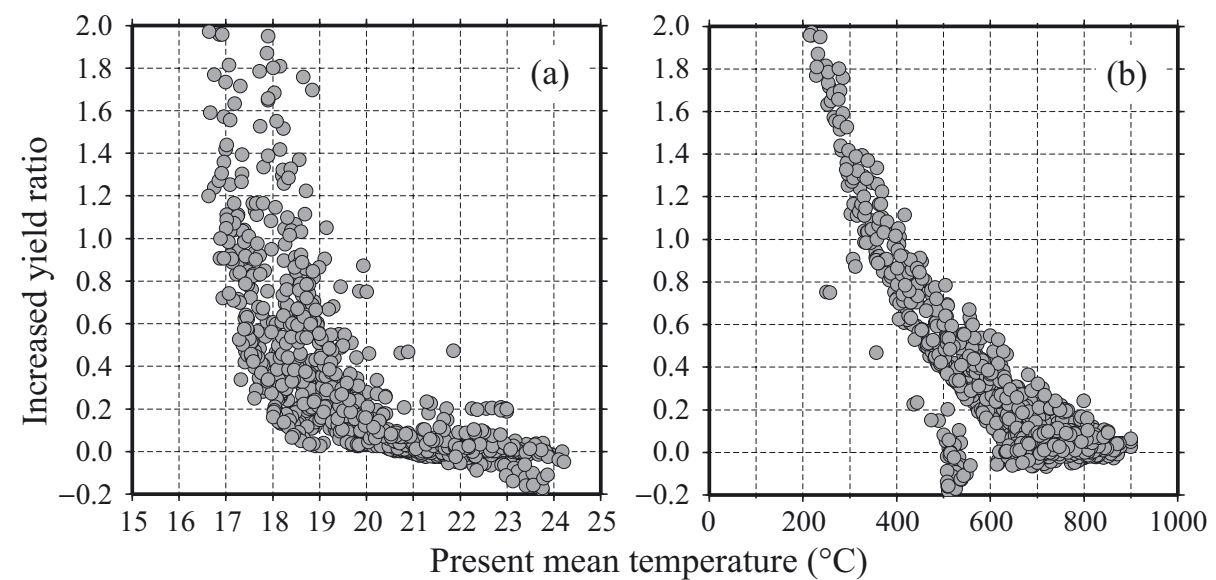

Fig. 6. Relationship between daily (a) mean temperature and (b) rice yield in the present climate and the increased yield ratio from the present to the future climate

creased-yield ratio (i.e. future yield/present yield) averaged $17 \%$, but differed between regions. It was $\sim 10 \%$ in the plains and $>40 \%$ in the mountainous areas and on Hokkaido (Fig. 5c), whereas a negative impact was found in several areas of the Japan Sea side and in a southern area with a higher estimated surface temperature (Fig. 2e). A high increased-yield ratio was found in the northern and high-elevation areas, so we focused on the relation between the increased-yield ratio and the present mean temperature. The negative correlation $(\mathrm{r}=-0.71)$ illustrated the high increased-yield ratio for low temperature (Fig. 6a). Present yield was more strongly related to the ratio $(r=-0.85)$, whereas a high ratio was estimated for the lower-yield area (Fig. 6b).

In the present climate, the rice crop was not exposed to high-temperature stress in eastern Japan (Fig. 7a), but the high-temperature stress became obvious in the future climate (Fig. 7b). In particular, the increase was more evident in the southern plains (Fig. 7c). The increased ratio of the future hightemperature stress normalized by the present stress (i.e. [future - present]/present) was $551 \%$ on average regionally. The ratio is large because of the small value in the present climate. On the other hand, the geographical distribution of low-temperature stress in the present climate followed the north-south gradient (Fig. 7d). Climate change had positive effects from the perspective of reducing cold damage, as the regional average of low-temperature stress in the future climate decreased to $36 \%$ of the present climate (Fig. 7e). In contrast to the situation for high-temperature stress, low-temperature stress was reduced in the northern or mountainous area (Fig. 7f). When we focused on the balance between high and low-temperature stresses, high-temperature stress was negligibly small in the present climate [ $f(\mathrm{HDD}): f(\mathrm{CDD})=1: 71]$. However, the intensity of the high-temperature stress increased a quarter of the value of the low-temperature stress under the future climate $[f(\mathrm{HDD}): f(\mathrm{CDD})=$ 1:3.9]. High-temperature stress was projected to increase in southern Japan and low-temperature stress was projected to decrease in the northern area.

\subsection{Potential cultivar shift due to climate change}

Fig. 8 shows a meridional distribution of the cultivar with the higher yield. More than one top cultivar is occasionally presented within the same latitudinal zones, because the best cultivars vary, depending on the variation in climatic conditions between east and west. The location of the top cultivar generally shifted northward in the future climate (Fig. 8a). In particular, Kirara397 (cultivar ID: 2), which was widely distributed as the top cultivar in the present climate, shifted and became limited to high latitudes or high altitudes in the future climate (corresponding to a sparse distribution in the south). A similar shift was found for Akitakomachi (ID: 5).

Hitomebore (ID: 1) was predominant in both climates (Fig. 8b). One of the northward-shifting cultivars, Kirara397 (ID: 2), occupied the highest share in the present climate $(37.6 \%)$, but decreased to $11.3 \%$ in the future climate. The decreased-share cultivars, such as Kirara397 or Akitakomachi, are sensitive to changes in the daily surface air temperature. This characteristic is expressed as the smaller value of $G_{2}$ and the larger value of $\alpha$ (Table 1). In contrast, the photoperiod-sensitive cultivars (larger $\beta$ value), such as Asahinoyume (ID: 4) or Aichinokaori (ID: 6), increased their share by $\sim 20 \%$. 

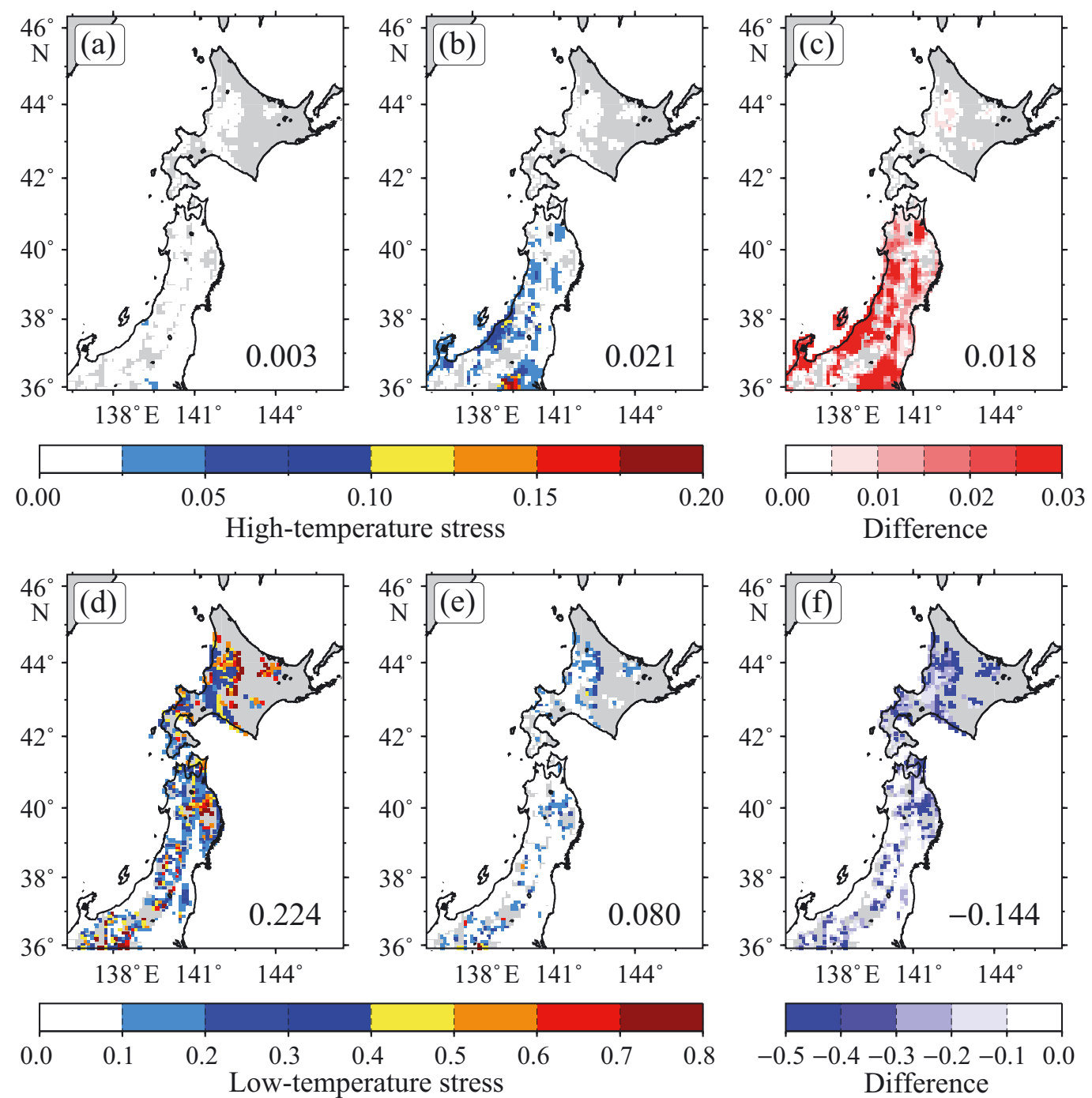

Fig. 7. Distribution of simulated temperature stress for the (a,d) present climate (1981-2000), (b,e) future climate (2081-2099), and $(\mathrm{c}, \mathrm{f})$ their difference (future climate - present climate): Function values of $(\mathrm{a}-\mathrm{c})$ high-temperature stress and $(\mathrm{d}-\mathrm{f})$ lowtemperature stress. Gray shading: areas with $<1 \%$ paddy fields in $10 \mathrm{~km}$ grid cells. Bottom right values: regional average

For the 3 major cultivars in the future climate (i.e. Hitomebore, Asahinoyume, and Aichinokaori), their distribution is shown for the present and future in Fig. 9. The Hitomebore grid cells are distributed throughout the study area except Hokkaido in the present climate, and they shift toward the north or the mountainous areas in the future climate. Asahinoyume and Aichinokaori, the photoperiod-sensitive cultivars, barely exist in the present climate, but become dominant in the southern plains in the future climate.

Yields averaged for the top cultivars in future climates were $26 \%$ higher than in the current climate. High yields were recorded for Asahinoyume and Aichinokaori, which are more photoperiod-sensitive than Hitomebore (Table 2). Growth duration, in days from transplanting to maturity, of these top cultivars were close to the current growth duration (MAFF, data as of 2009, www.maff.go.jp/j/study/suito_sakugara/ h2204/pdf/ref_data3-3.pdf), suggesting that these phenological traits match well to local future climates.

Based on the projected yield and temperature stress of the current leading cultivars (Figs. 5 \& 7), we analyzed the cultivars that provided more favorable outcomes (i.e. higher potential yield or lower temperature stress) than the current leading cultivars (Fig. 10). Additionally, we extracted the grid cells for which the current leading cultivar was ranked 6 or lower (i.e. 6 of the current non-leading cultivars surpassed the leading one) and designated them as reversed grid cells. For example, $53.9 \%$ of the paddy grid cells were selected as reversed grid cells when 


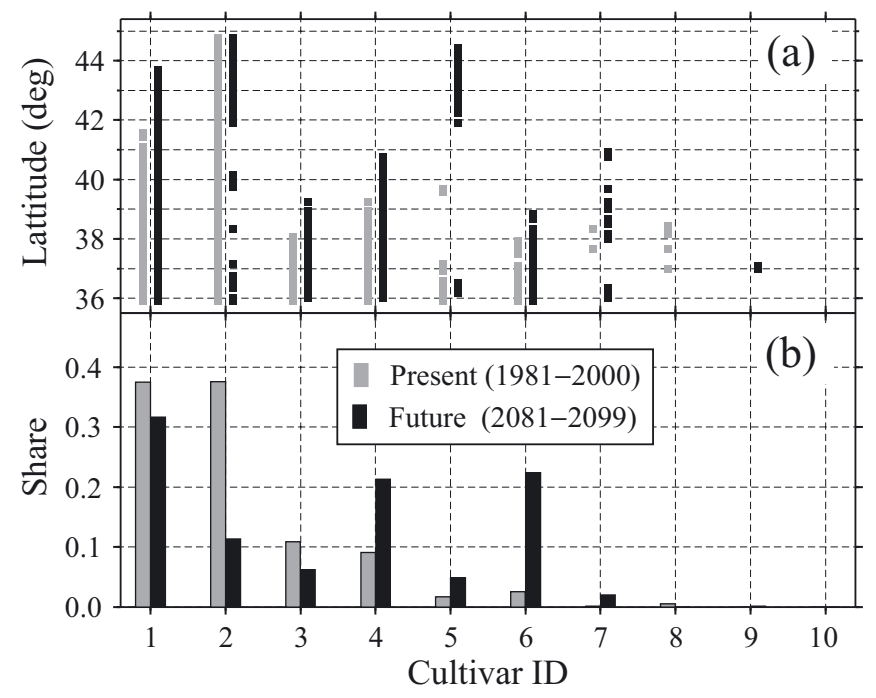

Fig. 8. (a) Meridional distribution of cultivars that provide the maximum yield among the 10 cultivars and (b) their share of the entire analyzed area. Gray/black = present/ future climate, respectively. Cultivar names for each ID are presented in Table 1

we focused on a potential yield (Fig. 10a). This tendency was more evident in the high-temperature stress case, with $86.8 \%$ of the total paddy grid cells (Fig. 10b). However, the ratio dropped to $10.4 \%$ for the low-temperature stress case (Fig. 10c).

Next, we performed the multi-condition assessment. Multi-condition assessment means that two or three conditions are considered concurrently for judgment of reversed grid cells. For the case of higher potential yield and less high-temperature stress, the southern area was expected to have a
Table 2. Future yield and growing period averaged over the grid cells for the 3 major simulated cultivars (i.e. maximum yield value among 10 cultivars)

\begin{tabular}{|lcc|}
\hline & Yield $\left(\mathrm{g} \mathrm{m}^{-2}\right)$ & $\begin{array}{c}\text { Growing } \\
\text { duration (d) }\end{array}$ \\
\hline Hitomebore (ID: 1) & 828 & 127 \\
Asahinoyume (ID:4) & 886 & 144 \\
Aichinokaori (ID: 6) & 937 & 154 \\
\hline
\end{tabular}

large proportion of reversed grid cells (Fig. 10d; $29.2 \%$ ), whereas the northern area had fewer because of difficulties in maintaining higher yield. As the decrease in low-temperature stress was more difficult for the current non-leading cultivars compared to high-temperature stress (Fig. 10b,c), the reversed grid cells under the condition of higher potential yield and less low-temperature stress were rarely found in eastern Japan (Fig. 10e; 5.2\%). Therefore, good performance under all 3 conditions (higher potential yield, less high-temperature, and less lowtemperature stresses, Fig. 10f) was limited to only a few grids and cultivars. In approximately $64 \%$ of the grid cells, the current leading cultivar was the top cultivar.

\section{DISCUSSION}

When the current leading cultivars were maintained in the future (2081-2099) climate, rice yield was projected to increase by an average of $17 \%$ compared with the baseline climate (1981-2000). The positive effect was mainly for 2 reasons: (1) increases in atmospheric $\mathrm{CO}_{2}$ concentrations $\left(C_{\mathrm{a}}\right)$ and (2) rise in temperatures from sub-optimal levels. In the simulation, mean $C_{a}$ for the baseline period was $354 \mathrm{\mu mol} \mathrm{mol}^{-1}$, but in the future period it reached $534 \mu \mathrm{mol} \mathrm{mol}{ }^{-1}$ under RCP 4.5 (Meinshausen et al. 2011). A meta-analysis of the previous free-air $\mathrm{CO}_{2}$ enrichment (FACE) studies showed a $12 \%$ increase in grain yield under the $C_{\mathrm{a}}$ range of 500 to $599 \mu \mathrm{mol} \mathrm{mol}^{-1}$ (Ainsworth 2008). A recent rice model intercomparison study demonstrated that current rice models also predict a yield increase of $\sim 14$ to $15 \%$, with an increase in $C_{\mathrm{a}}$ by $180 \mu \mathrm{mol} \mathrm{mol}{ }^{-1}$ (Li et al. 2015). These findings support that rising $C_{\mathrm{a}}$ is an important factor for the increase in rice yields. 

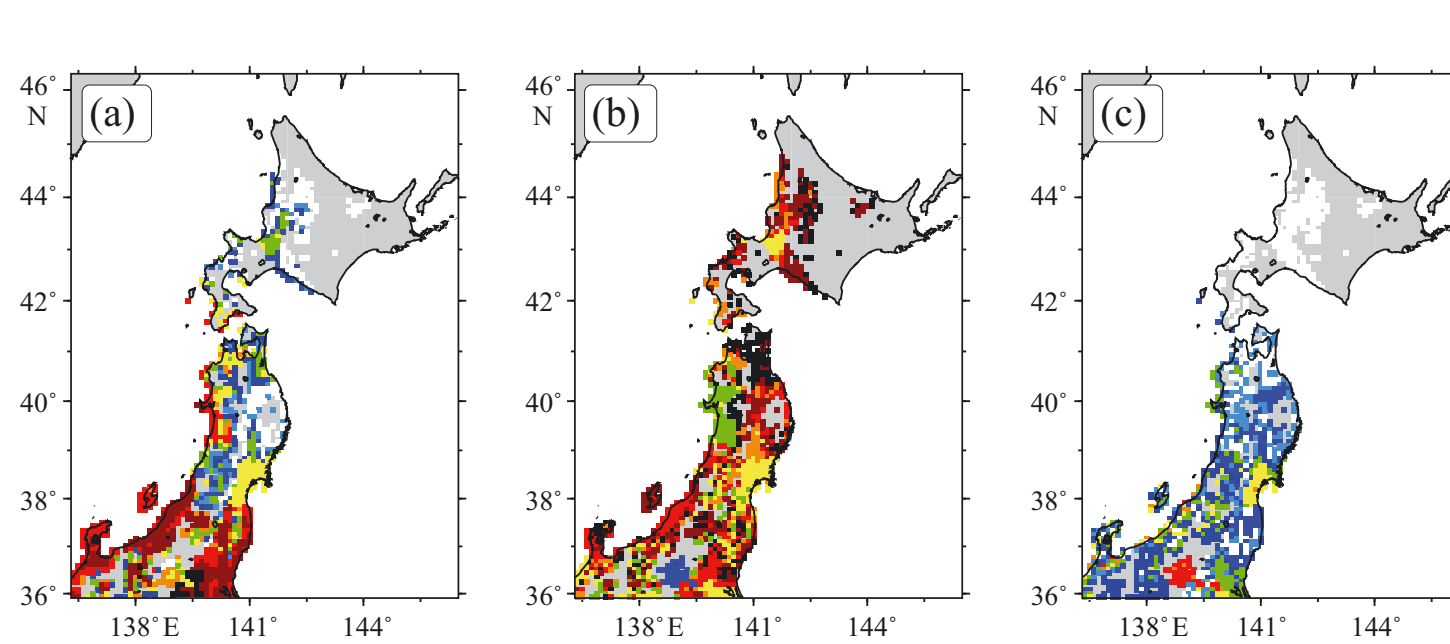

No. of cultivars
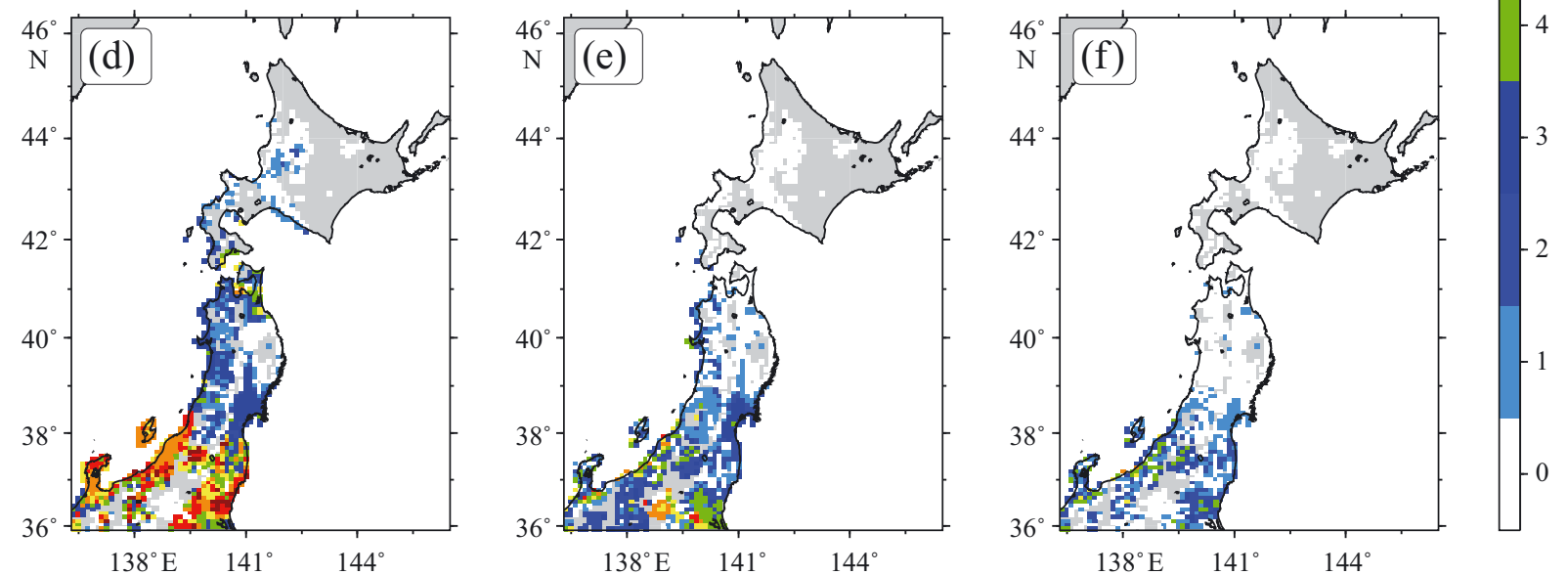

Fig. 10. Number of cultivars that provide more favorable rice production in the future climate than the current leading cultivar (i.e. higher potential yield, less high-temperature stress, and less low-temperature stress): (a) higher yield, (b) less hightemperature stress, (c) less low-temperature stress, (d) higher yield + less high-temperature stress, (e) higher yield + less low-temperature stress, and (f) higher yield + less high-temperature stress + less low-temperature stress. Gray shading: non-rice-cropped areas with $<1 \%$ paddy fields in the $10 \mathrm{~km}$ grid cells

Summer air temperature of $18.0^{\circ} \mathrm{C}$ averaged for the baseline period (Fig. 2a) is apparently cooler than the optimum, even for temperate japonica cultivars, whose optimal temperature range for the ripening process is 20 to $22^{\circ} \mathrm{C}$ (Yoshida 1981). The projected surface warming in this study was $\sim 3^{\circ} \mathrm{C}$ (Figs. 2c,f,i), and thus provided favorable conditions for rice growth. Our results for yields are consistent with the previous studies that demonstrated how a warming of 1 to $3^{\circ} \mathrm{C}$ brings favorable rice growth in the midlatitudes in contrast to the negative impact projected in the low latitudes (Nakagawa et al. 2003, Easterling et al. 2007). An observational study found that yields are currently increasing in northern Japan (Shimono 2008).

Several concerns remain despite these optimistic projections for the impacts of climate change. Our projections and other studies suggest that the risk of cold damage will persist in the future (Fig. $7 \mathrm{e}_{\text {; Kanda }}$ et al. 2014), so precautions for low-temperature stress are continuously required (Kanno 2004). Hightemperature stress was estimated to become more apparent in the future, and therefore, both stresses deserve attention. $\mathrm{CO}_{2}$ fertilization effects in rice are decreased under both low and high temperatures (Shimono 2008, Hasegawa et al. 2015), but the present model does not account for this interaction. Interaction between $\mathrm{CO}_{2}$ and temperature, in fact, is pointed out as the major source of uncertainties in the rice-yield predictions ( $\mathrm{Li}$ et al. 2015), and the $\mathrm{CO}_{2}$ fertilization may be smaller than expected. Future model evaluation must account for the $\mathrm{CO}_{2}$ and temperature interaction.

The present study is unique in that it examines whether cultivar shifts occur as a result of climate change among the widely planted cultivars in Japan 
at present based on 3 metrics: (1) potential yield, (2) cold stress, and (3) heat stress. A major decline was predicted for Kirara397 (ID: 2), an early maturing cultivar widely planted in Hokkaido at present. This cultivar was replaced with longer, but weakly photoperiod-sensitive cultivars, such as Hitomebore (ID: 1) and Akitakomachi (ID: 5) (Fig. 8a). Hitomebore (ID: 1) maintained its high share values in terms of yield under climate change conditions (Fig. 8b) by becoming the leading cultivar in the future climate (i.e. it was selected in most grid cells; Fig. 10a), while giving away several current 'winning' grid cells. This cultivar was developed in Miyagi Prefecture $\left(38^{\circ} \mathrm{N}\right.$, $140^{\circ} \mathrm{E}$ on the Pacific Ocean side, Fig. 1) in 1991 as a highly cold tolerant cultivar with a high eating quality. It is currently the second most popular cultivar in Japan and is widely planted across different regions, including southern prefectures such as Okinawa $\left(24^{\circ}-27^{\circ} \mathrm{N}\right)$ and Oita prefecture $\left(33^{\circ} \mathrm{N}\right.$, Fig. 1), with $13.7 \%$ of the total paddy area in 2009 (MAFF 2014). This wide adaptability could in part be attributed to a low temperature sensitivity of phenology, as evidenced by the smallest $\alpha$ value (Table 1), i.e. growth duration is relatively unaffected by the temperature change. This could be one of the key traits for stable rice production in the future climate. Two longerduration cultivars, Asahinoyume (ID: 4) and Aichinokaori (ID: 6) (Fig. 8b), gained share in the future climates. These cultivars are currently not major winners but are projected to become dominant in the southern plains (Fig. 9), suggesting that photoperiod sensitivity helps to ensure growth duration in relatively warmer regions.

When we consider all of the higher potential yields and reduced high- and low-temperature stresses, cultivar replacement was projected to occur in 35.6\% of the paddy grid cells, whereas the current leading cultivars kept their superiority in the remaining $64.4 \%$ grid cells (Fig. 10f). The regional yield average for the top cultivars, based on the multiple metrics, was $22 \%$ higher than the baseline. Of the new cultivars, those selected in each grid cell were developed in the more southern areas. When they are grown in the current climate, they take too long to mature, but under warmer conditions, they grow sufficiently long to ensure higher yield but without temperature stress. Thus, introducing the 'southern cultivars' would be an effective way to adapt to the future climate in approximately $36 \%$ of the study area. An observational study also suggested the introduction of a southern cultivar to mitigate the hightemperature damage projected for the current leading cultivars (Nemoto et al. 2011).
In approximately $64 \%$ of the grid cells, however, presently leading cultivars remained the winners if the 3 metrics are taken into account (Fig. 9f). This finding suggests that cultivar replacement is not an 'easy' option. Southern cultivars often failed to win despite many reverse grid cells based on a single metric (Figs. 9a-c). A trait such as low sensitivity to temperature for phenology observed for Hitomebore also helps current winners under climate change conditions because of its smaller variation in growth duration. This trait could also be a valuable trait under variable weather conditions. The results also suggest that breeding new cultivars for the future by utilizing or pyramiding higher yield potentials and stress tolerances is essential. Phenology is the first trait that needs to be considered for climate change adaptation, but keeping growth duration long is not the only way to improve productivity. In the context of climate change, enhancing the $\mathrm{CO}_{2}$ fertilization effect is an option for the future (Ziska et al. 2012). A previous FACE study demonstrated a large genotypic variability in the grain-yield response to elevated $C_{a}$, ranging from 3 to $36 \%$ (Hasegawa et al. 2013).

The current study is an initial attempt to account for multiple metrics to visualize a possible cultivar shift under climate change conditions. In reality, farmers' cultivar choices are more complex, with many more metrics taken into account. Marketability, eating, and appearance quality, in addition to pest, diseases, and lodging resistance, all count when choosing cultivars, all of which can be potentially influenced by climate change. Future work is required to link these metrics, as they directly affect the profitability of farmers.

\section{CONCLUSION}

This study evaluated adaptation to climate change for crop production based on multiple metrics and multiple choices of existing cultivars, taking the presently cool climate as an example for rice production in Japan. Projection based on the MIROC5 global climate model under RCP4.5 and a rice model $(\mathrm{H} / \mathrm{H})$ demonstrated that climate change in the 20812099 period would increase grain yield by a regional average of $17 \%$ compared with the baseline climate (1981-2000), even without any cultivar shift. The simulation also predicted that low-temperature stresses would be reduced but that high-temperature stresses would become apparent, suggesting that countermeasures against both heat and cold damages will be required in the future climate. 
Comparisons of simulations among 10 major Japanese cultivars demonstrated that top cultivars change dramatically with climate change if only a single metric, such as yield, is accounted for. The predicted yield averaged for the yield 'winners' was $26 \%$ higher than the baseline yield. When all 3 metrics (yield, cold and heat stress) are taken into account, however, cultivar replacement is projected to occur in $\sim 36 \%$ of the grid cells, and the current leading cultivars maintained their superiority in $\sim 64 \%$ of the total grid cells. The resultant yield advantage compared with the baseline was $22 \%$. This finding suggests a requirement for developing new cultivars by pyramiding useful traits for the future climates. A trait such as low sensitivity to temperature for phenology helps in ensuring growth duration under variable temperatures. Increasing photoperiod sensitivity can be an option in the future climates in relatively warmer regions.

Future studies must include other important metrics, such as quality and profitability, in combination with management practices, including crop calendar and fertilizer managements. Uncertainties from climate projections and crop models should also be combined with the benchmark testing of these adaptation measures.

Acknowledgements. This study was supported by JSPS KAKENHI (Grant No.: 25892004), Asahi Group Foundation, the Research Program on Climate Change Adaptation (RECCA) of the Ministry of Education, Culture, Sports, Science, and Technology of Japan, the Environment Research and Technology Development Fund (S-8-1) of the Ministry of the Environment, Japan, and the Cross-ministerial Strategic Innovation Promotion Program of the Cabinet Office, Government of Japan. The $\mathrm{H} / \mathrm{H}$ model improvement was conducted through a research project entitled 'Development of technologies for mitigation and adaptation to climate change in agriculture, forestry and fisheries, ' funded by the Ministry of Agriculture, Forestry and Fisheries, Japan. We thank Dr. Shinji Sawano for providing N fertilizer input data converted from the Production Cost Statistics.

\section{LITERATURE CITED}

Ainsworth EA (2008) Rice production in a changing climate: a meta-analysis of responses to elevated carbon dioxide and elevated ozone concentration. Glob Change Biol 14: 1642-1650

Challinor A, Wheeler T, Hemming D, Upadhyaya H (2009) Ensemble yield simulations: crop and climate uncertainties, sensitivity to temperature and genotypic adaptation to climate change. Clim Res 38:117-127

Collatz GT, Ball JT, Grivet C, Berry JA (1991) Physiological and environmental regulation of stomatal conductance, photosynthesis and transpiration: a model that includes a laminar boundary layer. Agric Meteorol 54:107-136
Collins M, Knutti R, Arblaster J, Dufresne JL and others (2013) Long-term climate change: projections, commiments and irreversibility. In: Stocker TF, Qin D, Plattner G-K, Tignor M and others (eds) Climate change 2013: the physical science basis. Contribution of Working Group I to the Fifth Assessment Report of the Intergovernmental Panel on Climate Change. Cambridge University Press, Cambridge

> Deryng D, Sacks WJ, Barford CC, Ramankutty N (2011) Simulating the effects of climate and agricultural management practices on global crop yield. Glob Biogeochem Cycles 25:GB2006, doi:10.1029/2009GB003765

> Deryng D, Conway D, Ramankutty N, Price J, Warren R (2014) Global crop yield response to extreme heat stress under multiple climate change futures. Environ Res Lett 9:034011,

Easterling WE, Aggarwal PK, Batima P, Brander KM and others (2007) Food, fiber and forest products. In: Parry ML, Canziani OF, Palutikof JP, van der Linden PJ, Hanson CE (eds) Climate change 2007: impacts, adaptation and vulnerability. Contribution of Working Group II to the Fourth Assessment Report of the Intergovernmental Panel on Climate Change. Cambridge University Press, Cambridge, p 273-313

Farquhar GD, von Caemmerer S, Berry JA (1980) A biochemical model of photosynthesis $\mathrm{CO}_{2}$ assimilation in leaves of $\mathrm{C}_{3}$ species. Planta 149:78-90

Fukui S, Ishigooka Y, Kuwagawa T, Hasegawa T (2015) A methodology for estimating phenological parameters of rice cultivars utilizing data from common variety trials. J Agr Meteorol 71:77-89, doi:10.2480/agrmet.D-14-00042

Hasegawa T, Horie T (1997) Modelling the effect of nitrogen on rice growth and development. In: Kropff MS, Teng PS, Aggarwal PK, Bouma J, Bouman BAM, Jones JW, van Laar HH (eds) Applications of systems approaches at the field level. Kluwer, Dordrecht, p 243-257

Hasegawa T, Ishimaru T, Kondo M, Kuwagawa T, Yoshimoto M, Fukuoka M (2011) Spikelet sterility of rice observed in the record hot summer of 2007 and the factors associated with its variation. J Agric Meteorol 67:225-232

Hasegawa T, Sakai H, Tokida T, Nakamura H and others (2013) Rice cultivar responses to elevated $\mathrm{CO}_{2}$ at two free-air $\mathrm{CO}_{2}$ enrichment (FACE) sites in Japan. Funct Plant Biol 40:148-159,

Hasegawa T, Sakai H, Tokida T, Usui Y and others (in press) (2015) Rice FACE studies to improve assessment of climate change effects. In: Hatfield JL, Fleisher D (eds) Improving modeling tools to assess climate change effects on crop response. Adv Agric Syst Model Ser, American Society of Agronomy, Madison, WI, doi: 10.2134/advagricsystmodel7.2014.00158

Horie T, Nakagawa H, Centeno HGS, Fropff MJ (1999) The rice crop simulation model SIMRIW and its testing. In: Matthews RB, Kropff MJ, Bachelet D, van Laar HH (eds) Modeling the impact of climate change on rice production in Asia. International Rice Research Institute and CAB International, Wallingford, p 51-66

> Iizumi T, Hayashi Y, Kimura F (2007) Influence on rice production in Japan from cool and hot summers after global warming. J Agric Meteorol 63:11-23

> Iizumi T, Nishimori M, Ishigooka Y, Yokozawa M (2010) Introduction to climate change scenario derived by statistical downscaling. J Agric Meteorol 66:131-143 (in Japanese with English abstract)

> Iizumi T, Yokozawa M, Nishimori M (2011) Probabilistic evaluation of climate change impacts on paddy rice productivity in Japan. Clim Change 107:391-415, 
Ishizaki NN, Takayabu I, Oh'izumi M, Sasaki H and others (2012) Improved performance of simulated Japanese climate with a multi-model ensemble. J Meteorol Soc Jpn 90:235-254

Kain JS (2004) The Kain-Fritch convective parameterization: an update. J Appl Meteorol 43:170-181

Kanda E, Kanno H, Okubo S, Shimada T, Yoshida R, Kobayashi $T$, Iwasaki $T$ (2014) Estimation of cool summer damage in the Tohoku region based on the MRI AGCM. J Agric Meteorol 70:187-198, doi:10.2480/agrmet.D-1400004

Kanno H (2004) Five-year cycle of north-south pressure difference as an index of summer weather in northern Japan from 1982 onwards. J Meteorol Soc Jpn 82:711-724

Kanno H, Watahabe M, Kanda E (2013) MIROC5 predictions of Yamase (cold northeasterly winds causing cool summers in northern Japan). J Agric Meteorol 69:117-125

Kassie B, Asseng S, Rotter R, Hengsdijk H, Ruane AC, Van Ittersum MK (2015) Exploring climate change impacts and adaptation options for maize production in the Central Rift Valley of Ethiopia using different climate change scenarios and crop models. Clim Change 129:145-158, doi:10.1007/s10584-014-1322-x

Katul GG, Ellsworth DS, Lai CT (2000) Modeling assimilation and intercellular $\mathrm{CO}_{2}$ from measured conductance: a synthesis of approaches. Plant Cell Environ 23:1313-1328

Kim HY, Ko J, Kang S, Tenhunen J (2013) Impacts of climate change on paddy rice yield in a temperate climate. Glob Chang Biol 19:548-562

Kimura F, Kitoh A (2007) Downscaling by pseudo global warming method. In: The Final Report of the ICCAP. Research Institute for Humanity and Nature (RIHN), Kyoto

Li T, Hasegawa T, Yin X, Zhu Y and others (2015) Uncertainties in predicting rice yield by current crop models under a wide range of climatic conditions. Glob Chang Biol 21: 1328-1341

Lobell DB, Field CB (2007) Global scale climate-crop yield relationships and the impacts of recent warming. Environ Res Lett 2:014002, doi:1088/1748-9326/2/1/014002

MAFF (Ministry of Agriculture, Forestry and Fisheries) (2000) Crop statistics. Association of Agriculture and Forestry Statistics, Tokyo

MAFF (2014) Crop statistics. MAFF, Tokyo

- Medlyn BE, Badeck FW, De Pury DGG, Barton CVM and others (1999) Effects of elevated $\left[\mathrm{CO}_{2}\right]$ on photosynthesis in European forest species: a meta-analysis of model parameters. Plant Cell Environ 22:1475-1495

Meinshausen M, Smith SJ, Calvin K, Daniel JS and others (2011) The RCP greenhouse gas concentrations and their extensions from 1765 to 2300. Clim Change 109:213-241

MLITT (Ministry of Land, Infrastructure, Transport and Tourism) (2012) National Land Numerical Information. MLITT, Tokyo

Nakagawa H, Horie T, Matsui T (2003) Effects of climate change on rice production and adaptive technologies. In: Mew TW, Brar DS, Peng S, Dawe D, Hardy B (eds) Rice science: innovations and impact for livelihood. IRRI, Chinese Academy of Engineering, and Chinese Academy of Agricultural Sciences, p 635-658

- Nakagawa H, Yamagishi J, Miyamoto N, Motoyama M, Yano M, Nemoto K (2005) Flowering response of rice to photoperiod and temperature: a QTL analysis using a phenological model. Theor Appl Genet 110:778-786

Nakanishi M, Niino H (2004) An improved Mellor-Yamada level-3 model with condensation physics: its design and verification. Boundary-Layer Meteorol 112:1-31

Nemoto M, Hamasaki T, Sameshima R, Kugawai E, Ohno H,
Wakiyama Y, Maruyama A, Ozawa K (2011) Assessment of paddy rice heading date under projected climate change conditions for Hokkaido region based on the field experiment. J Agric Meteorol 67:275-284

Nemoto M, Hamasaki T, Sameshima R, Kumagai E and others (2012) Probabilistic risk assessment of the rice cropping schedule for central Hokkaido, Japan. J Appl Meteorol Climatol 51:1253-1264

> Okada M, Iizumi T, Hayashi Y, Yokozawa M (2011) Projecting climate change impacts both on rice quality and yield in Japan. J Agric Meteorol 67:285-295

Parry ML, Rosenzweig C, Iglesias A, Livermore M, Fischer G (2004) Effects of climate change on global food production under SRES emissions and socio-economic scenarios. Glob Environ Change 14:53-67

Porter JR, Xie L, Challinor AJ, Cocharane $\mathrm{K}$ and others (2014) Food security and food production systems. In: Field CB, Barros VR, Dokken DJ, Mach KJ, and others (eds) Climate change 2014: impacts, adaptation, and vulnerability. Part A: global and sectoral aspects. Contribution of Working Group II to Fifth Assessment Report of the Intergovernmental Panel on Climate Change. Cambridge University Press, Cambridge, p 485-553

Rosenzweig C, Elliott J, Deryng D, Ruane AC and others (2014) Assessing agricultural risks of climate change in the 21st century in a global gridded crop model intercomparison. Proc Natl Acad Sci (USA) 111:3268-3273,

Saito K, Ishida J, Aranami K, Hara T, Segawa T, Narita M, Honda Y (2007) Nonhydrostatic atmospheric models and operational development at JMA. J Meteorol Soc Jpn 85B:271-304

Satake T (1976) Sterile-type cool injury in paddy rice plants. In: Climate and rice. International Rice Research Institute, Los Baños, p 281-300

Satake T, Yoshida S (1978) High temperature-induced sterility in indica rices at flowering. Jpn J Crop Sci 47:6-17,

Seino H (1993) An estimation of distribution of meteorological elements using GIS and AMeDAS data. J Agric Meteorol 48:379-383

- Shimono H (2008) Impact of global warming on yield fluctuation in rice in the northern part of Japan. Jpn J Crop Sci 77:489-497 (in Japanese with English abstract),

> Shimono H (2011) Earlier rice phenology as a result of climate change can increase the risk of cold damage during reproductive growth in northern Japan. Agric Ecosyst Environ 144:201-207

Shimono H, Okada M, Yanakawa Y, Nakamura H, Kobayashi K, Hasegawa T (2008) Rice yield enhancement by elevated $\mathrm{CO}_{2}$ is reduced in cool weather. Glob Change Biol 14:276-284

Soora N, Aggarwal PK, Saxena R, Rani S, Jain S, Chauhan N (2013) An assessment of regional vulnerability of rice to climate change in India. Clim Change 118:683-699

Tao F, Hayashi Y, Zhang Z, Sakamoto T, Yokozawa M (2008) Global warming, rice production, and water use in China: developing a probabilistic assessment. Agric Meteorol 148:94-110

Wassmann R, Jagadish SVK, Heuer S, Ismail A and others (2009) Climate change affecting rice production: the physiological and agronomic basis for possible adaptation strategies. Adv Agron 101:59-122

Watanabe M, Suzuki T, O'ishi R, Komuro Y and others (2010) Improved climate simulation by MIROC5: mean states, variability, and climate sensitivity. J Clim 23: 6312-6335

Yin X, Kropff MJ, Horie T, Nakagawa H, Centeno HGS, Zhu D, Goudriaan J (1997) A model for photothermal 
responses of flowering in rice I. Model description and parameterization. Field Crops Res 51:189-200

Yoshida S (1981) Fundamentals of rice crop science. International Rice Research Institute, Los Baños

Yoshida R, Iizumi T, Nishimori M (2012a) Inter-model differences in the relationships between downward shortwave radiation and air temperatures derived from dynamical and statistical downscaling models. J Meteorol Soc Jpn 90B:75-82

Yoshida R, Iizumi T, Nishimori M, Yokozawa M (2012b) Impacts of land-use changes on surface warming rates

Editorial responsibility: Gerrit Hoogenboom,

Prosser, Washington, USA and rice yield in Shikoku, western Japan. Geophys Res Lett 39:L22401, doi:10.1029/2012GL053711

Yu Y, Zhang W, Huang Y (2014) Impact assessment of climate change, carbon dioxide fertilization and constant growing season on rice yields in China. Clim Change 124:763-775

Ziska LH, Bunce JA, Shimono H, Gealy DR and others (2012) Food security and climate change: on the potential to adapt global crop production by active selection to rising atmospheric carbon dioxide. Proc R Soc B 279: 4097-4105

Submitted: August 25, 2014; Accepted: June 3, 2015 Proofs received from author(s): August 25, 2015 